\title{
UPAYA PELESTARIAN KULINER KHAS MINANGKABAU PADA POLA MAKAN KELUARGA MINANG PERANTAUAN
}

\author{
Siska Amania Putri' ${ }^{1}$, Ade Juwaedah ${ }^{1}$, Karpin ${ }^{1}$ \\ Program Studi Pendidikan Tata Boga, Departemen Pendidikan Kesejahteraan \\ Keluarga, Fakultas Teknologi dan Kejuruan, Universitas Pendidikan Indonesia
}

\section{leeminha6735@gmail.com}

\begin{abstract}
Abstrak: Suku Minangkabau secara geografis berada di Sumatera Barat, Indonesia dan terkenal dengan kegigihan dalam membudayakan tradisi budaya makan melalui keluarga dengan berbagai macam ciri khas masing-masing dari tiap daerah. Selain terkenal dengan tradisi budaya makan, masyarakat Minangkabau juga terkenal dengan tradisi merantau, merantau keluar pulau bagi masyarakat Minangkabau sudah menjadi kebiasaan bahkan sudah menjadi suatu keharusan dan dilakukan dalam jangka waktu yang lama, tetapi masih tetap mempertahankan tradisinya bahkan meluaskannya di daerah perantaun. Tujuan skripsi ini untuk mendapat inforasi terkait: (1) pola makan keluarga Minangkabau perantauan, (2) melindungi kuliner khas Minangkabau, (3) merawat kuliner khas Minangkabau, (4) memanfaatkan sumber daya pada kuliner khas Minangkabau (populer di restoran dan tradisi rumahan). Penelitian ini menggunakan metode deskriptif dengan pendekatan kuantitatif dengan instrument berupa angket dan essay terbatas yang memuat konten upaya pelestarian, sampel yang digunakan sebanyak 58 mahasiswa Minang perantauan yang terhimpun dalam komunitas di Universitas Pendidikan Indonesia. Hasil dari penelitian diteliti dari aspek pola makan, didapati hasil bahwa pola makan mahasiswa Minang perantauaan masih menjadikan kuliner khas Minangkabau sebagai makanan utama dengan frekuensi makan di siang hari lebih banyak, namum tidak menutup kemungkinan mengkonsumsi kuliner dari daerah lain. Hasil penelitian berdasarkan aspek upaya melindungi, merawat dan memanfaatkan sumber daya secara keseluruhan dinyatakan baik, namun prioritas upaya paling tinggi berada pada memanfaatkan sumber daya dengan mengkonsumi kuliner khas Minangkabau..
\end{abstract}

Kata kunci : Upaya Pelestarian, Kuliner Khas Minangkabau, Pola Makan

\section{PENDAHULUAN}

\begin{tabular}{llr}
\multicolumn{2}{c}{ Kebudayaan memiliki ciri } \\
tertentu dalam menggambarkan \\
kehidupan masyarakat yang \\
menganutnya, dan memberi warna \\
tertentu khususnya pada masyarakat \\
Minangkabau. Salah satu warna yang \\
diberikan kebudayaan & pada \\
masyarakat & Minangkabau yaitu
\end{tabular} kuliner. Kebudayaan berkaitan dengan konsumsi mendefinisikan apa yang pantas untuk dimakan dan terkadang apa yang dimakan dapat menunjukkan keanggotaan dalam suatu kebudayaan atau sub kebudayaan (Erda Fitriani, 2012, hlm 136). Pada umumnya kebudayaan pada kuliner akan membentuk pola makan baik individu maupun kelompok dan seringkali merefleksikan latar belakang etnik atau daerah lokasi geografis tertentu.

Kuliner dalam suatu masyarakat berbudaya memiliki makna simbolik dan diterima secara rutin sejak usia muda dalam perjalanan kehidupan, dan biasanya sulit untuk diubah. Hal ini berkaitan dengan pendapat kuliner merupakan suatu bagian hidup yang erat kaitannya dengan konsumsi makanan dalam sehari-hari yang dilakukan oleh individu maupun kelompok (Ryanto : 2015). Namun 
dengan berkembangnya gaya hidup dan tingkat aktifitas yang cukup padat mendorong individu untuk melakukan berbagai hal dengan cara yang lebih praktis membuat beberapa kebiasaan yang sudah ditanamkan sejak dini mengalami beberapa perubahan, terutama dalam hal kuliner pada pola makan keluarga Minangkabau di tanah rantau. Pemilihan makanan pada individu ataupun kelompok sangat kompleks, dan dipengaruhi oleh beberapa faktor seperti dari faktor ekonomi, sosial budaya, agama, pendidikan, lingkungan, dan kebiasaan makan (Sulistyoningsi, 2011).

Perubahan yang berlangsung akibat berkembangnya gaya hidup individu maupun kelompok berpengaruh pada pola makan keluarga baik dari kebiasaan makan makanan modern seperti fastfood, makanan yang diadopsi dari negara barat, modifikasi dan bahkan sebagian lebih memilih mengkonsumsi kuliner khas daerah lain dimana mereka menetap dengan mengutamakan selera atau cita rasa yang sesuai dengan lidah mereka.

Berkembangnya gaya hidup yang terjadi perlu diiringi dengan upaya pelestarian dengan tujuan untuk mempertahankan sesuatu yang sudah ada sesuai dengan pendapat A.W Widjaja (dalam Ranjabar : 2006, hlm 115) yang mengemukakan bahwa pelestarian sebagai kegiatan atau yang dilakukan secara terus menerus, terarah dan terpadu guna mewujudkan tujuan tertentu yang mencerminkan adanya sesuatu yang tetap dan abadi, bersifat dinamis, luwes dan selektif.

Secara teknik upaya dan perubahan, manusia dalam hal ini dikatakan sebagai alat dalam menjalankan upaya pelestarian. Pelestarian merupakan sebuah upaya yang akan mendasar dan dasar ini disebut juga faktor-faktor yang mendukung baik dari dalam maupun dari luar dari hal yang dilestarikan, maka dari itu sebuah proses atau tindakan pelestarian mengenal strategi ataupun teknik yang didasarkan pada kebutuhan dan kondisinya masingmasing.

Berdasarkan pemaparan yang telah dijelaskan sebelumnya, bahwa generasi muda rentan mengalami perubahan gaya hidup seiring dengan berkembangnya zaman, maka perlu adanya penguatan dan penanaman unsur kebudayaan sesuai dengan apa yang berlaku di dalam keluarga seperti pada pola makan yang dibiasakan, pola makan didefinisikan sebagai kebiasaan yang diolah dalam rangka pelestarian kuliner. Pelestarian yang dilakukan dapat dilakukan dalam beberapa bentuk seperti pendapat menurut Nia Kurmasih (1992, hlm 36) yang menyatakan upaya peletarian suatu budaya dapat dilakukan dalam berbagai bentuk seperti perlindungan, perawatan dan pemanfaatan sumber daya untuk menjadikan budaya tersebut tetap bertahan.

Berdasarkan uraian latar belakang, penulis merasa penting untuk mengetahui lebih lanjut tentang "Upaya Pelestarian Kuliner Khas Minangkabau Pada Pola Makan Minang Perantauan". Aspek upaya pelestarian meliputi; perlindungan, perawatan dan pemanfaatan sumber daya, sedangkan pada aspek pola makan meliputi; jenis makan, frekuensi makan dan jumlah makan, namun pada jenis makan dibedakan berdasarkan kuliner yang populer di restoran dan populer di rumahan dengan didasari bahan dasar dan bumbu dasar yang digunakan. 
Rumusan masalah penelitian ini yaitu "Bagaimana upaya pelestarian kuliner khas Minangkabau pada pola makan keluarga Minang perantauan?"

Tujuan dalam penelitian ini adalah untuk memperoleh gambaran mengenai konsumsi kuliner khas Minangkabau sebagai menu harian di keluarga Minang perantauan, meliputi: (1) Mengetahui pola makan keluarga Minang perantauan, (2) Mengetahui upaya melindungi kuliner khas Minangkabau, (3) mengetahui upaya merawat kuliner khas Minangkabau (4) mengetahui upaya memanfaatkan kuliner khas Minangkabau (populer di restoran dan tradisi rumahan).

\section{METODE PENELITIAN}

Metode penelitian yang digunakan adalah metode penelitian deskriptif dengan tujuan untuk mendapatkan gambaran dari suatu keadaan yang ada pada masa sekarang dan sedang berlangsung serta berpusat pada masalah yang aktual (Arikunto, 2013, hlm. 3). Subjek penelitian seluruh mahasiswa yang tergabung ke dalam Forum Silaturahmi Mahasiswa Minangkabau atau FOSMI di Universitas Pedidikan Indonesia dengan jumlah populasi 231 orang. Sampel dalam penelitian ini adalah Simple Random Sampling sehingga mengambil sampel sebanyak 58 orang.

Pengumpulan data berupa angket dan essay terbatas dengan memuat konten upaya pelestarian. Sebelum menyebarkan data, penulis melakukan uji validitas isi atau content validity untuk memastikan bahwa item skala yang digunakan sudah memenuhi keseluruhan isi konsep atau kesesuaian item. Sebanyak 55 butir soal dengan 5 pilihan jawaban kemudian disebarkan kepada 58 orang responden melalui aplikasi google docs. Selanjutnya instrumen diperiksa dan diberikan skor 5 untuk pilihan jawaban sangat positif hingga sangat negatif dengan skor1. Jawaban responden kemudian ditabulasi menggunakan bantuan Microsoft Excel 2013 . Instrumen yang telah diskor dipersentasekan dan dikategorikan mengadopsi pendapat yang dikemukan oleh Riduwan (2011, hlm.15) yaitu sebagai berikut:

$$
\begin{array}{ll}
81 \%-100 \% & =\text { Sangat tinggi } \\
61 \%-80 \% & =\text { Tinggi } \\
41 \%-60 \% & =\text { Cukup } \\
21 \%-40 \% & =\text { Rendah } \\
0 \%-20 \% & =\text { Sangat rendah }
\end{array}
$$

\section{HASIL DAN PEMBAHASAN}

Pola makan pada setiap masyarakat merupakan suatu kategori budaya yang penting karena berhubungan dengan berbagai unsur yang terdapat di dalam budaya yang berlaku di masyarakat yang menganutnya. Salah satunya pada masyarakat Minangkabau yang dimana memiliki keragaman budaya karena sistem sosialnya yang kuat, terutama dalam hal konsumsi yang dilakukan sehari-hari atau untuk konsumsi adat istiadat. Pola makan pada masyarakat Minangkabau merupakan sebagai suatu yang kompleks dengan kegiatan masakmemasak, suka dan tidak suka, kearifan rakyat, kepercayaan, pantangan dan tahayul yang berkaitan dengan produksi, persiapan dan konsumsi makanan (Foster dan Anderson: 1986, hlm 313). Pola makan yang dilakukan oleh setiap individu merupakan gambaran yang sama dengan kebiasaan makan yang 
dilakukan di dalam keluarga dan yang didefinisikan sebagai kebiasaan yang diolah dalam rangka pelertarian kuliner mencangkup beberapa aspek yaitu melindungi, merawat dan memanfaatkan sumber daya.

Data hasil penelitian pola makan pada keluarga Minangkabau perantauan berkaitan dengan jenis makan yang dilakukan dalam keseharian, diketahui bahwa mahasiswa keturunan Minangkabau masih memilih jenis makan khas Minangkabau sebagai makanan utama dengan persentase $62 \%$ dengan jumlah responden 36 orang yang menyatakan sering. Hal ini menunjukkan bahwa jenis makan khas Minangkabau berada pada kriteria tinggi sebagai makanan utama dan tetap menjadi pilihan utama masyarakat Minangkabau sebagai makanan yang dikonsumsi setiap hari meskipun berada di tanah perantauan.

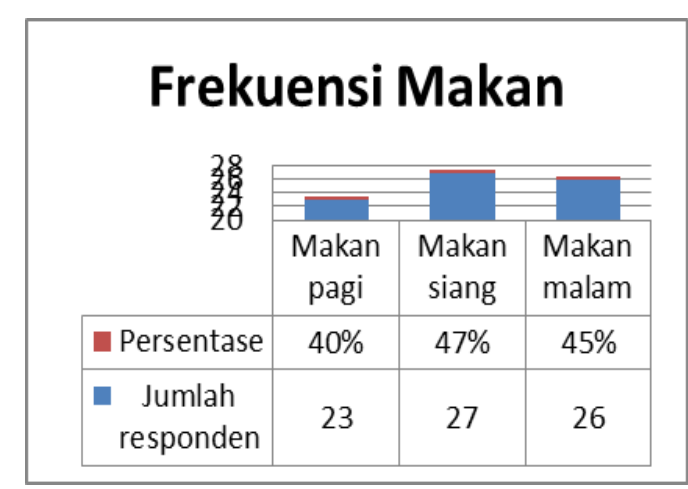

Sumber: hasil pengolahan instrumen pernyataan no 2-4

Gambar1 Presentase Pola Makan

Berdasarkan Frekuensi Makan

Data hasil penelitian pola makan pada keluarga Minangkabau perantauan berkaitan dengan frekuensi makan, sebagian besar masyarakat Minangkabau lebih memilih kuliner khas Minangkabau sebagai hidangan di siang hari dan malam hari dan dinyatakan ke dalam kriteria cukup dengan presentase di atas $41 \%$. Terakhir untuk indikator jumlah makan, dinyatakan ke dalam kriteria rendah dengan persentase $38 \%$. Hal ini menunjukkan bahwa sebagian besar responden dapat mengkonsumsi kuliner lain di luar kuliner khas Minangkabau dalam jumlah porsi besar sesuai dengan selera. Sesuai dengan yang dikemukakan oleh Erda Fitria (2012, hlm 139) bahwa sebagian besar masyarakat Minangkabau mengkonsumsi makanan dalam jumlah porsi makan sebanyak 2 sampai 3 piring dalam sekali makan apabila mengkonsumsi makanan yang disukai dengan mengikuti selera dan tidak hanya berlaku pada menu harian tetapi juga pada penyelenggaraan upacara adat.

Pelestarian merupakan sebuah upaya yang berdasar dan dasar ini disebut juga faktor-faktor yang mendukung baik dari dalam maupun dari luar dari hal yang dilestarikan, maka dari itu sebuah proses atau tindakan pelestarian mengenal strategi ataupun teknik yang didasarkan pada kebutuhan dan kondisinya masingmasing. Menurut Nia Kurmasih (1992, hlm 36) pelestarian dilakukan dalam beberapa bentuk meliputi perlindungan, perawatan dan pemanfaatan sumber daya yang memiliki tujuan masing-masing.

Data hasil penelitian berdasarkan upaya melindungi kuliner tradisi khas Minangkabau pada mahasiswa Minangkabau perantauan, didapati hasil bahwa upaya pelestarian dalam hal perlindungan berada pada kriteria cukup dengan persentase $41 \%$ dan merupakan sub indikator tertinggi diantara yang lain yang masih berada 
pada kriteria rendnag dengan persentase $40 \%$ kebawah. Hal ini menunjukkan bahwa upaya pelestarian dalam hal perlindungan kuliner khas Minangkabau dalam keluarga dapat diartikan cukup baik tetapi masih belum sesuai dengan harapan atau ekspetasi. Pada upaya pelestarian dengan indikator perlidungan memiliki maksud bahwa upaya yang dilakukan merupakan upaya yang dilakukan untuk mencegah kerusakan dari luar, seperti adanya pengaruh budaya baru dan budaya luar yang akan merusak atau menggantikan salah satu unsur atau kepercayaan yang sudah dipegang teguh oleh masyarakat yang menganut budaya tersebut.

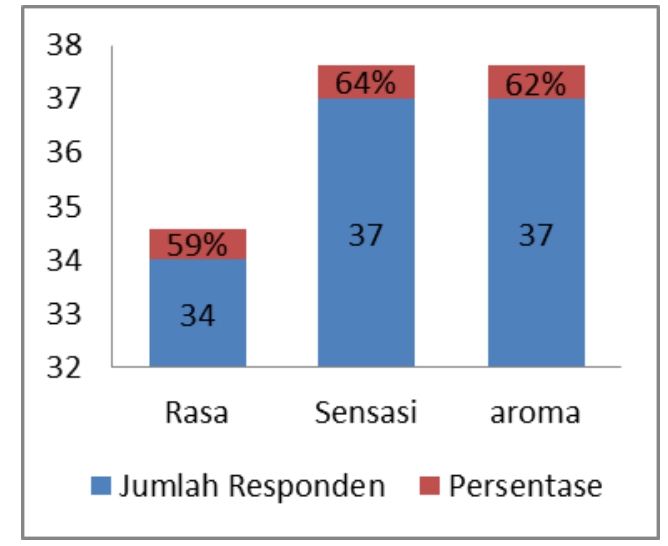

Sumber: hasil pengolahan intrumen pernyataan no 11-20

Gambar 2 Presentase Upaya Merawat

Kuliner Khas Minangkabau

Berdasarkan Penggunaan Bumbu

Dasar

Presentase jawaban responden mengenai upaya merawat tradisi kuliner khas Minangkabau berdasarkan bumbu dasar secara keseluruhan berada pada kriteria baik dengan persentase di atas $40 \%$ keluar dari kriteria rendah dengan presentase terbesar sebanyak 64\% dengan jumlah responden 37 orang, sedangkan untuk upaya merawat tradisi kuliner berdasarkan bumbu dalam meningkatkan berada diurutan terakhir dengan 59\% dengan jumlah responden sebanyak 34 orang dan termasuk ke dalam kategori cukup.

Tingginya presentase jawaban responden disebabkan karena sebagian responden ada yang mengenal bahan bumbu dalam kuliner Minangkabau tetapi tidak ataupun jarang menggunakan bahan bumbu tersebut, atau responden mengenal bahan bumbu dalam kuliner Minangkabau dan sering pula menggunakan bumbu dasar tersebut dalam proses pengolahan. Sedangkan rendahnya presentase dapat disebabkan karena sebagian kecil responden sering menggunakan baham bumbu tersebut tetapi tidak mengenal nama ataupun ciri dari bumbu yang digunakan atau bahkan tidak mengenal dan tidak pernah menggunakan bumbu dasar tersebut dalam proses pengolahan masakan Minangkabau.

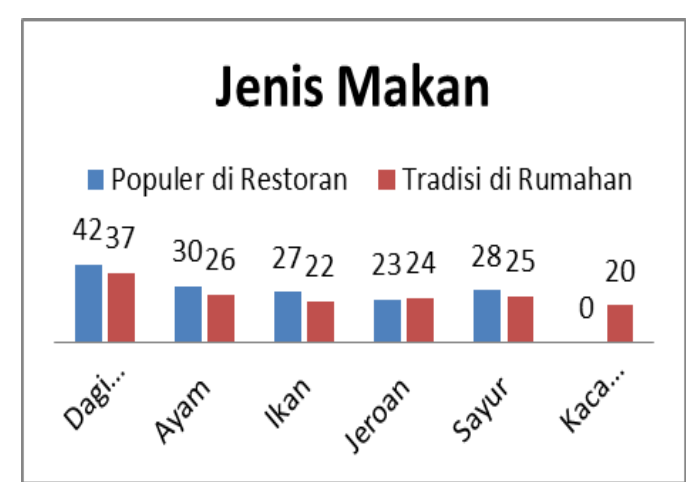

Sumber: hasil pengolahan instrumen pernyataan no 21-55

Gambar 3 Presentase Upaya

Memanfaatkan Sumber Daya Dengan

Konsumsi Kuliner Khas Minangkabau

Berdasarkan Bahan Dasar

Pada hasil penelitian upaya memanfaatkan sumber daya dengan konsumsi kuliner khas Minangkabau 
berdasarkan bahan dasar menunjukkan bahan dasar daging berada pada urutan pertama dengan jumlah responden pada kuliner Minangkabau yang populer di restoran 42 orang dengan hidangan rendang sebagai hidangan yang sering dikonsumsi dan 37 orang untuk kuliner tradisi di rumahan gulai kurma sebagai kuliner yang tidak pernah dikonsumsi. Hal ini menunjukkan bahwa sebagian besar responden mengkonsumsi kuliner Minangkabau tetapi tidak mengetahui nama hidangan, atau tidak pernah mengkonsumsi dan tidak mengetahui nama hidangan khas Minangkabau.

Presentase jawaban tertinggi responden yaitu $72 \%$ yang berada pada kriteria tinggi, sedangkan responden yang menjawab terendah yaitu $34 \%$ yang berada pada kriteria rendah untuk hindangan berbahan dasar kacang-kacangan pada kuliner tradisi rumahan. Sejalan dikemukakan pada bab 2 bahwa pola makan pada masyarakat Minangkabau merupakan sebagai sesuatu yang kompleks dengan kegiatan masak-memasak, suka dan tidak suka, kearifan rakyat, kepercayaan, pantangan dan tahayul yang berkaitan dengan produksi, persiapan dan konsumsi makanan (Foster dan Anderson: 1986, hlm 313).

Sesuai dengan teori yang dikemukan oleh Foster dan Anderson (1986, hlm 312) bahwa pemilihan pada makanan yang diperngaruhi oleh pengalaman sewaktu kecil dalam suatu keluarga akan berpengaruh pada kegemaran setelah dewasa, makanan yang dikenal semasa kanak-kanak tetap menarik, sedangkan yang baru dikenal setelah dewasa lebih mudah ditolak. Maka dapat disimpulkan masyarakat Minangkabau yang semasa kecilnya lebih banyak mengenal makanan khas Minangkabau maka, makanan itulah yang akan menjadi kegemarannya

Berdasarkan hasil pemaparan secara keseluruhan didapati bahwa upaya pelestarian kuliner khas Minangkabau pada keluarga Minang perantauan dilihat dari pola makan yang di definisikan sebagai kebiasaan yang diolah dalam rangka pelestarian kuliner dengan mencangkup melindungi, merawat dan memanfaatkan sumber daya berada pada kriteria cukup dengan persentase meskipun bila melihat secara satu persatu masih ada yang berada di bawah $41 \%$ dan ada pula yang berada di atas 60\%, sedangkan pada hasil essay menunjukkan bahwa adanya hubungan antara hasil angket dan hasil essay yang menyatakan upaya pelestarian pada pola makan keluarga Minang perantauan masih tetap dilaksanakan sesuai harapan dan ekspetasi dengan melihat beberapa persamaan diksi atau makna pada jawaban responden yang menunjukkan adanya pola pengajaran tentang tradisi makan dalam keluarga.

\section{SIMPULAN IMPLIKASI DAN REKOMENDASI \\ Simpulan}

Berdasarkan penelitian yang dilakukan mengenai Upaya Pelestarian Kuliner Khas Minangkabau Pada Pola Makan Keluarga Minang Perantauan, maka secara umum diperoleh kesimpulan bahwa hasil dari presentase instrumen mengenai pola makan berdasarkan jenis makan, frekuensi makan dan jumlah makan menunjukan bahwa responden sebagian besar masih mengkonsumsi kuliner khas Minangkabau sebagai makanan utama dengan persentase $62 \%$ dengan frekuensi makan tertinggi pada makan siang dengan persentase 
47\% dan $38 \%$ untuk jumlah makan, sehingga secara keseluruhan masuk pada kategori cukup dan dinyatakan sesuai dengan harapan dan ekspetasi dengan melihat latar belakang terfokus pada responden di tanah perantauan.

Hasil dari presentase instrumen mengenai upaya pelestarian kuliner khas Minangkabau pada keluarga Minang perantauan berdasarkan perlindungan, perawatan dan pemberdayaan sumber daya menunjukan bahwa sebagian besar indikator memiliki angka persentase di atas $41 \%$ sehingga berada pada kategori cukup hingga tinggi dan dinyatakan sesuai dengan harapan atau ekspetasi, dibalik berbagai macam aspek yang dialami oleh generasi muda khususnya pada mahasiswa Minangakabu di perantauan dalam berkembangnya zaman.

\section{Implikasi dan Rekomendasi}

Implikasi dari penelitian ini apabila dilihat dari hasil kesimpulan adalah pola makan mahasiswa Minangkabau berdasarkan jenis makan, frekuensi makan dan jumlah makan memiliki hasil angket berkategori sedang. Hal tersebut menunjukan bahwa sebagian besar mengkonsumsi kuliner khas Minangkabau dan sebagian tidak mengkonsumsi kuliner khas Minangakabu. Sehingga diperlukan pembiasaan, dorongan dan pengenalan yang menyeluruh mengenai kuliner khas Minangkabau dalam keluarga baik kuliner sehari-hari atau kuliner adat.

Upaya pelestarian kuliner khas Minangkabau pada keluarga Minang perantauan berdasarkan perlindungan, perawatan dan pemanfaatan sumber daya memiliki hasil angket rendah. Hal tersebut menunjukkan bahwa upaya pelestarian kuliner khas Minangkabau pada keluarga belum dilakukan secara menyeluruh dan diperlukan dorongan atau pengenalan yang menyeluruh mengenai kuliner khas Minangkabau dalam keluarga baik kuliner sehari-hari atau kuliner adat.

Berdasarkan hasil analisis dan kesimpulan penelitian sebagaimana yang sudah dijelaskan, maka penulis sampaikan beberapa rekomendasi seperti Sebaiknya mampu bersikap dengan baik, upaya mana yang harus dipertahankan dalam menghargai dan mana yang harus di hilangkan dalam upaya pelestarian kuliner khas daerah agar generasi selanjutnya dapat mewariskan hidangan tersebut sehingga tidak punah khususnya kuliner khas Minangkabau. Upaya pelestarian dapat dilakukan dengan berbagai cara baik perlindungan, perawatan dan pemanfaatan sumber daya sejak dini dengan mengenalkan nama, bahan dasar dan teknik mengolah hidangan tersebut.

\section{REFERENSI}

Afriyanti, Fisra. (2016). Don't Stop Exploring West Sumatra. Jakarta. Pt. Elex Media Kumputindo.

Anas, ZaidanNur dkk. (1984/1985). Makanan Wujud, Variasi, dan Fungsinya. Padang. Departemen Pendidikan dan Kebudayaan

Anderson, dkk (1986). Berita Antropologi. Univ of California. Univ Indonesia, Fakultas Sastra.

Arikunto, S. (2013). Prosedur Penelitian. Jakarta : Rineke Cipta

Ariyanti, Nur Indah (2013). Strategi

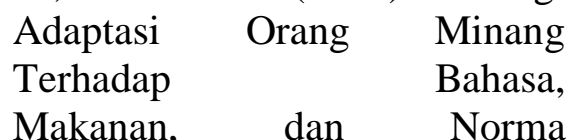


Masyarakat Jawa. Purwokerto. Jurnal Komunitas. Jilid 1

Besra, Eri. (2012). Potensi Wisata Kuliner Dalam Mendukung Pariwisata di Kota Padang. Jurnal Riret Akuntansi dan Bisnis Vol.12 No.1 (Maret 2012)

Departemen Pendidikan Nasional. (2016). Pedoman Penulisan Karya Ilmiah. Bandung: UPI

Endarmoko, Eko. (2006). Tesaurus Bahasa Indonesia. Jakarta. PT Gramedia Pustaka Utama

Fitriani, Erda (2012).Pola Kebiasaan Makan Orang Lanjut Usia
Sukubangsa Minangkabau. Padang. Vol. XI No.2

Sugiyono. (2016). Metode Penelitian Pendidikan. Bandung : Alfabeta. Sulistyoningsi, Hariyani. (2011). Gizi dan Kesehatan Ibu dan Anak. Yogyakarta. Graha Ilmu

Suradisastra, Kedi. Dkk (2015). Peran Lembaga Adat Kerapatan Adat Nagari Dalam Mekanisme Alih Informasi Pertanian di Sumatera Barat

Sjoekri, Rima (2017). Seni Rasa Teman Resep Masakan Indonesia. Jakarta. Pt. Gramedia Pustaka Utama 